\title{
Study on the efficacy of Palandu Ghrita in the Management of Sutured Clean Lacerated Wound w.s.r. To Hypertrophic scar
}

\author{
Case Report
}

\author{
Shekokar Anantkumar ${ }^{1}$, Borkar Kanchan ${ }^{2}$, Badhiye Sanjeevani $^{3 *}$ \\ 1. Professor, 2. Associate Professor, 3. Post Graduate Scholar \\ Department of Shalya Tantra, SVNHT's Ayurved Mahavidyalaya, Rahuri Factory.
}

\begin{abstract}
Ayurveda is a science of life and is believed to exist as long as the origin of life on this nature as it mentioned in Charak Samhita. Ever since, the life originated, human being has been susceptible to injury which is made him to think about healing.

Hypertrophic scar is a type of scar characterized by hypertrophy or proliferation of mature fibroblast or fibrous tissue without proliferation of blood vessels. It is caused due to tissue formation during healing process. Acharya Sushruta has mentioned Palandu (Allium Cepa) as Sthirdhatukarta and Krumighna. Palandu is one of the oldest cultivated vegetables in indian history. Palandu contains vitamin A, C and proteins which are essential factors for wound healing, with keeping these factors in mind,present study was planned as a local application of Palandu Ghrita to prevent hypertrophic scar because prevention is better than cure.

For this research study we designed 2 groups viz. experimental group (Group A) i.e. application of Palandu Ghrita and control group (Group B) i.e. application of plain gauze piece. In this, we observed 30 patients from each group according to age, occupation, family history, sharir prakruti etc. and made result on the basis of assessment criteria like pain, scar colour, pliability, tenderness etc. By taking all observations into consideration we made result by using Wilcoxon signed rank test and Mann Whitney's $U$ test and came on the conclusion that Palandu Ghrita application prevents hypertrophic scar with economical and easy acceptability.
\end{abstract}

Keywords: Hypertrophic scar, palandu ghrita, lacerated wound.

\section{Introduction}

The history of medical sciences starts with the art and skill of wound healing. Treatment of wound is probably the first medical problem faced by human beings. The frequency of injuries is more common than any other disease.

While explaining the scope of Shalya Tantra, Sushruta has mentioned Vrana as a major part of surgery. As per Svabhavoparamvaad (1) stated that healing of any pathology happens naturally. Therefore, healing of Vrana is also a natural process of the body but Vrana should be protected from Dosha-Dushti and from various micro-organisms, which may afflict the Vrana and affected the normal healing process. From the ancient period, after the discontinuity of skin causes the wound (2) called Vrana which heals and forms Vranavastu (3) that means scar. This scar never disappear for the rest of life. Acharya Sushruta has minute observation about this Vranavastu (Scar) that it looks very ugly.

Surgery is an art and suturing is a fine art. The people in the present era are too much conscious about their cosmetic look. In case of repair of external skin

\section{*Corresponding Author:}

\section{Badhiye Sanjeevani}

Post Graduate Scholar,

Department of Shalya Tantra,

SVNHT's Ayurved Mahavidyalaya,

Rahuri Factory

Email: sanjeevanibadhiye@gmail.com injury and after undergoing surgical procedure, everybody demands that there should be no scar or minimum scar formation. People are even under go cosmetic surgery to get rid of their ugly scars. Keeping this fact in view, in the field of surgical practice, lot of emphasis has been given for search of scar less preventive treatment.

Hypertrophic scar (4) is a type of scar characterized by hypertrophy or proliferation of mature fibroblast or fibrous tissue without proliferation of blood vessels. It is caused due to tissue formation during healing process. Hypertrophic scars are indurate, elevated, poorly extensible and also characterized by hypervascularity thereby providing their erythematous appearances. In modern science there are treatments (5) to cure hypertrophic scar such as topical medical applications, cryotherapy, use of silicone gel sheets, injection of steroids, radiotherapy, surgical excision, dermabrasion, pressure therapy, pulse dye and carbon dioxide laser ablations. But these techniques are unreliable, unpredictable, expensive, long hospitalization and causes chemical irritations. Due to steroid therapy skin looks reddish and thinnest which can causes rodent ulcers or basal cell carcinoma (6) commonly over face.

Acharya Sushruta has mentioned Palandu (Allium Cepa) as Sthirdhatukarta (7) and Krumighna. Palandu is one of the oldest cultivated vegetables in history. This contain a readily and highly researched bioflavonoids (8) with antihistamine and antiproliferative effects on both normal and malignant cells. These properties could 
theoretically prove beneficial in reversing the inflammatory and proliferative responses. Palandu contains vitamin $\mathrm{A}, \mathrm{C}$ and proteins which are essential factors for wound healing (9). Palandu contains $80 \%$ of moisture which prevents Kshaya of Rasa Dhatu. It is Madhur Rasatmak Dravya (10) which helps in Sandhan Karma of Vrana. we were taking this study as a local application of Palandu Ghrita to prevent hypertrophic scar because prevention is better than cure.

\section{Aims and Objectives}

Aim

To study the efficacy of Palandu Ghrita in the management of sutured clean lacerated wound to prevent hypertrophic scar.

\section{Objectives}

To study properties of Palandu Ghrita like Krumighna, Sthirdhatukarta, Sukharopaniya.

\section{Material and Methods \\ Palandu Ghrita}

1) Palandu

2) Goghrita

Table no. 1 Description of Paland $u$ and Goghrita

\begin{tabular}{|c|c|c|}
\hline & Palandu & Goghrita \\
\hline 1.Family & Liliaceae & - \\
\hline 2.Latin Name & Allium cepa linn & - \\
\hline 3.English Name & Onion & Butter \\
\hline 4. Rasa & Madhur, Katu & Madhur \\
\hline 5.Guna & $\begin{array}{l}\text { Guru, Tikshna, } \\
\text { Snigdha }\end{array}$ & $\begin{array}{l}\text { Guru, Mridu, } \\
\text { Snigdha }\end{array}$ \\
\hline 6.Virya & Ishat Ushna & Sheeta \\
\hline 7.Vipak & Madhur & Madhur \\
\hline 8.Karma & $\begin{array}{l}\text { Sthirdhatukarta, } \\
\text { Krumighna, } \\
\text { Shulaghna, } \\
\text { Hridya, } \\
\text { Balya, } \\
\text { Vatakaphahara }\end{array}$ & $\begin{array}{l}\text { Vata-Pittaghna, } \\
\text { Rakshoghna, } \\
\text { Vranaropan }\end{array}$ \\
\hline $\begin{array}{l}\text { 9.Chemical } \\
\text { Composition }\end{array}$ & $\begin{array}{l}\text { Vit. A, C, B, } \\
\text { protein, } \\
\text { Carbohydrate, } \\
\text { Water, } \\
\text { Calcium, Iron, } \\
\text { Sulphur, } \\
\text { Quercetin }\end{array}$ & $\begin{array}{l}\text { Vit. A, D,E,K, } \\
\text { Linoleic acid, } \\
\text { Fatty Acid, Beta } \\
\text { carotene }\end{array}$ \\
\hline $\begin{array}{l}10 . \text { Mode of } \\
\text { action according } \\
\text { to modern. }\end{array}$ & $\begin{array}{l}\text { Antibacterial, } \\
\text { Antidiabetic, } \\
\text { Antioxidant, } \\
\text { Antifungal }\end{array}$ & $\begin{array}{l}\text { Antioxidant, } \\
\text { Good for Eyes \& } \\
\text { skin }\end{array}$ \\
\hline
\end{tabular}

Table no. 2 Chemical composition Palandu

\begin{tabular}{|l|l|}
\hline Water & 89.6 \\
\hline Protein & 1.2 \\
\hline Fat & 0.1 \\
\hline Carbohydrates & 11.1 \\
\hline Fiber & 0.6 \\
\hline Minerals & $0.4 \mathrm{~g} / 100 \mathrm{~g}$ \\
\hline Calcium & 47.0 \\
\hline Phosphorus & 50.0 \\
\hline Iron & 0.7 \\
\hline Thiamine & 0.08 \\
\hline Vitamin C & $11.0 \mathrm{mg} / \mathrm{kg}$ \\
\hline
\end{tabular}

\section{Method of preparation for Palandu Ghrita}

As per given in Sharangdhar Samhita, we made Palandu Ghrita by Snehapak Siddhi Kalpana(11) as follows-

- All equipment should be clean, dried and sterilized.

- All ingredients should be weighed properly.

- A clean vessel with wide mouth should be taken.

- Put 4 parts of Goghrita, heat on Mandagni till foam appears.

- Now add 1 part of Palandu Kalka and 16 part of Jala to it.

- Frequent stirring is required to avoid carbonization.

- Heating should be continued till the appearance of Sneha Siddhi Lakshnas for Khara Pak as mentioned above.

- After Lakshnas are obtained, filter the Sneha through cloth.

- Store the Sneha in the air tight container to use for present study.

\section{How to use}

- It is for external use only.

- Clean affected area.

- Apply small amount topically to affected area 1-3 times daily.

- May cover with sterile bandage.

\section{Mechanism of action}

When applied locally it produces nascent oxygen which creates plane of cleavage between lining tissue and slough and removal of slough mechanically due to release of catalase.

It produces effervescence on application which removes the bacteria. Its foaming action wash outs the bacteria. It has short duration of action and mechanically causes removal of tissue debris. It creates heat when applied locally, causing coagulation of proteins and also provides hemostasis.

\section{Inclusion criteria}

1. Age- 16 to $70 \mathrm{yrs}$.

2. Sex- Female.

3. Patients of Clean lacerated wound or tidy wound was selected. 
4. Site-Face.

5. Wound size- $2.5 \times 2.5 \times 01 \mathrm{~cm}$.

6. Duration of wound- less than 6hrs.

7. Clean lacerated wound related to twaka and mansa only.

8. Wound shape - Edges parallel to each other.

\section{Exclusion criteria}

1. Wound duration more than $6 \mathrm{hrs}$.

2. Hemoglobin $<10$ gm $\%$.

3. Patients having abnormal bleeding disorders (Increased BT \& CT).

4. Keloid, PBC (Post Burn Contracture).

5. Site- other than face.

6. Clean lacerated wound with other complications like fractures, head injury, marmaghat etc.

7. Patients having medico legal problems.

8. Sutured wound after $7^{\text {th }}$ day.

9. Patients who are not willing to participate in trial.

10. Patients suffering from systemic diseases such as AIDS, Tuberculosis, Diabetes mellitus, Hepatitis-B, Malignancy, Varicose ulcer, Deep vein thrombosis, Arterial ulcer, neurogenic ulcer, Leprosy, Pregnancy etc.

\section{Laboratory investigation}

1. $\mathrm{CBC}$

2. Erythrocyte sedimentation rate

3. B.T \& C.T

4. Blood sugar level.

5. HIV (if necessary)

6. HBsAg (if necessary).

7. Urine Routine.

8. Urine microscopic examination.

Suture type: Simple interrupted suture

Dose: As per wound 2 times a day

\section{Duration of treatment} Up to 45 days

\section{Observation Parameters}

1. Vedana (Pain)

2. Sparshasahatva (Tenderness)

3. Strava (Discharge)

4. Inflammation

5. Pliability

6. Consistency

7. Scar height

8. Scar color

9. Extension of scar

Group A Treated with Palandu Ghrita application comprised of 34 patients. Among them, 04 patients left the treatment against medical advice.

Group B Treated with Plane gauze piece application comprised of 32 patients. Among them 02 patients left the treatment against medical advice.
Table No. 3: Observation of 60 patients according to Age

\begin{tabular}{|c|c|c|c|c|}
\hline \multirow{2}{*}{$\begin{array}{c}\text { Age } \\
\text { (in Years) }\end{array}$} & \multicolumn{2}{|c|}{ No. of patients } & \multirow{2}{*}{ To- } & $\%$ \\
\cline { 2 - 3 } & $\begin{array}{c}\text { Group } \\
\text { A }\end{array}$ & $\begin{array}{c}\text { Group } \\
\text { B }\end{array}$ & \\
\hline $16-20$ & 02 & 05 & 07 & 11.66 \\
\hline $21-30$ & 05 & 04 & 09 & 15 \\
\hline $31-40$ & 12 & 10 & 22 & 36.66 \\
\hline $41-50$ & 05 & 04 & 09 & 15 \\
\hline $51-60$ & 04 & 05 & 09 & 15 \\
\hline $61-70$ & 02 & 02 & 04 & 06.66 \\
\hline
\end{tabular}

It was found that maximum number of patents i.e. $36.66 \%$ belonged to age group of $31-40$ years, $15 \%$ patient belonged to $21-30,41-50,51-60$ years of age group each, while $11.66 \%$ patients belonged to $16-20$ years and $06.66 \%$ of patients belonged to $61-70$ years of age group.

Table no. 4: Observation 0 f 60 patients according to Built

\begin{tabular}{|c|c|c|c|c|}
\hline \multirow{2}{*}{ Built } & \multicolumn{2}{|c|}{ No. of patients } & \multirow{2}{*}{ Total } & \multirow{2}{*}{} \\
\cline { 2 - 3 } & Group A & Group B & & \\
\hline Normal & 08 & 09 & 17 & 28.33 \\
\hline $\begin{array}{c}\text { Under } \\
\text { weight }\end{array}$ & 05 & 03 & 08 & 13.33 \\
\hline Obese & 17 & 18 & 35 & 58.33 \\
\hline
\end{tabular}

The table has shown that out of 60 patients studied, the maximum numbers of patients i.e. $58.33 \%$ have observed were obese whereas $28.33 \%$ were had normal built and $13.33 \%$ were underweight.

Table no. 5: Observation of 60 patients according to Scar colour

\begin{tabular}{|c|c|c|c|c|}
\hline \multirow{2}{*}{$\begin{array}{c}\text { Scar } \\
\text { colour }\end{array}$} & \multicolumn{2}{|c|}{ No. of patients } & \multirow{2}{*}{ Total } & \% \\
\cline { 2 - 3 } & Group A & Group B & & \\
\hline Normal & 19 & 14 & 33 & 55 \\
\hline Red & 06 & 07 & 13 & 21.66 \\
\hline Black & 05 & 09 & 14 & 23.33 \\
\hline
\end{tabular}

The table has shown that out of 60 patients studied, the maximum numbers of patients have observed were normal scar colour 55\% whereas $21.66 \%$ have red, $23.33 \% \%$ had black.

\section{Graph no. 1: Observation of 60 patients according to} wound site on face

Wound site on face

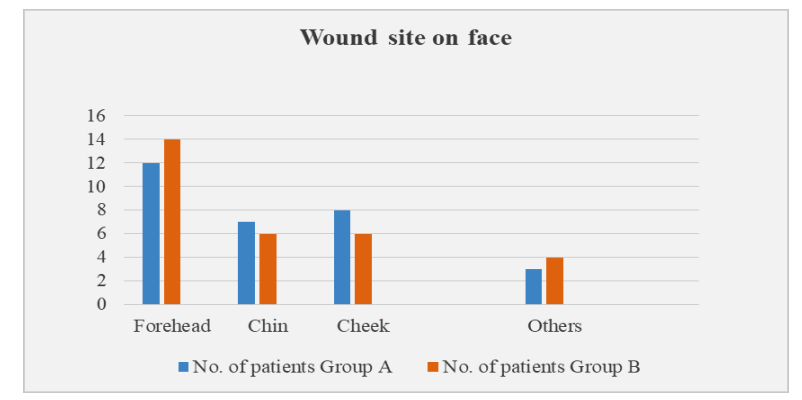




\section{Graph no. 2: Overall effect of therapy on clinical features in Group A}

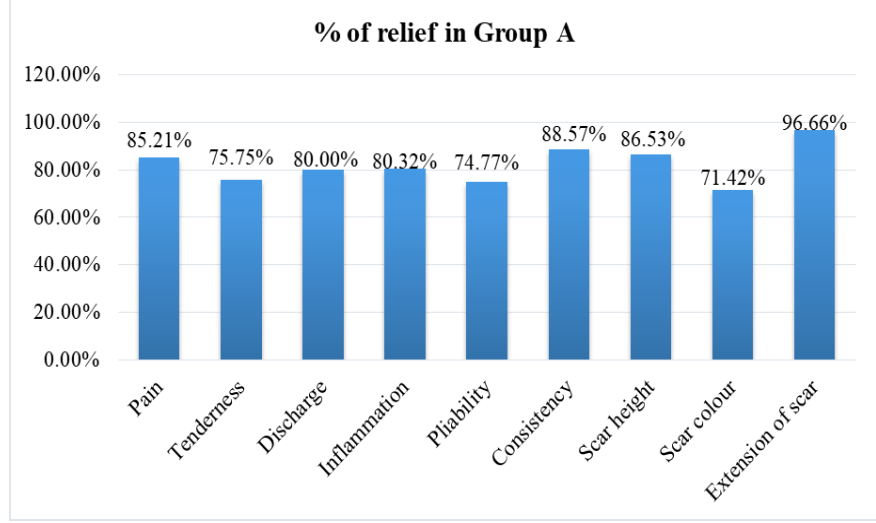

In group A, $\%$ of relief was obtained among 30 patients of sutured clean lacerated wound - relief in pain was $85.21 \%$, relief in tenderness was $75.75 \%$, relief in discharge was $80 \%$, relief in inflammation was $80.32 \%$, relief in pliability i.e. elasticity of scar was $74.77 \%$, relief in consistency of scar was $88.57 \%$, relief in scar height was $86.53 \%$, relief in scar color was $71.42 \%$, relief in extension of scar was $96.66 \%$.

\section{Graph No. 3: Overall effect of therapy on clinical features in Group B}

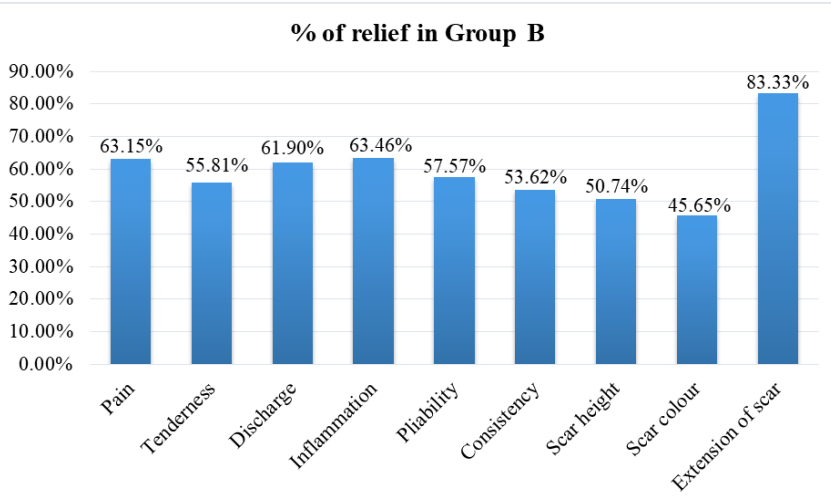

\section{Probable mode of action}

Among the ingredients of Palandu Ghrita drugs are having Madhur Rasa, Guru, Snigdha Guna and Sheeta Veerya, so these drugs are very effective to break the pathogenesis of Sadyovrana w.s.r. to hypertrophic scar as well by Virtue of these properties Palandu Ghrita simultaneously acts as a Shodhan and Ropana.

Acharya Sushruta has mentioned Palandu (Allium Cepa) as Sthirdhatukarta and Krumighna. Palandu contains $80 \%$ of water which prevents Kshaya of Rasa Dhatu and also dryness of wound on other hand it provides moisture to wound. It is Madhur Rasatmak Dravya which helps in Sandhan Karma of Vrana.

Action on the basis of Veerya: Due to Sheeta Veerya of ghrita it has properties of Ropan, mrudukarma. It plays important role to soften the wound due to sheeta virya.

As per morphology, Palandu is made up of very thin layers just like human skin. So according to Samanya Vishesh sidhant ${ }^{(84]}$ we conclude that each layer of Palandu acts on each layer (7 layers) of human skin for wound healing.

This contain a readily and highly researched bioflavonoids with antihistamine and antiproliferative effects on both normal and malignant cells. These properties could theoretically prove beneficial in reversing the inflammatory and proliferative responses. Palandu contains vitamin A, C and proteins which are essential factors for wound healing.

At the time of presentation, the patient had pain, discharge, tenderness etc., with predominating Vata Dosha. After application of Palandu ghrita, Madhura Rasa of the Palandu as well as Goghrita reduced the vitiated Vata Dosha, leading to reduced pain and enhanced healing.

Onion bulb mainly contains $1.2 \%$ protein, $11.6 \%$ carbohydrate, calcium, iron, vitamin A, B and C. Onion bulb contain a good number of phytochemicals most of which are hydrocarbons and their derivatives. These includes-

Dipropyl disulphide (which is used as flavor compound), Allicin (which has antidiabetic, antibiotic and antithrombotic properties.), Diathyl sulphide (which has insecticidal property).

Onion cgontain Sulphur compounds which acts as anti-inflammatory.

Goghrita also contains Vitamin A, D, E and K. Vitamins $\mathrm{A}$ and $\mathrm{E}$ are anti-oxidant and are helpful in preventing oxidative injury to the body.

\section{Conclusion}

Depending on the observations obtained and detailed discussion on this observation, following conclusion can be drawn.

Hypertrophic scar formation is commonly seen in obese female who has Rasakshayata and of Vata-pitta prakruti.

To prevent hypertrophic scar is an important factor for the healing of wound. Hypertrophic scar control was obtained in patients by external application of Palandu ghrita.

Palandu contains $80 \%$ of moisture which prevents rasa dhatu kshya; the dhatu mainly important in wound healing.

Palandu acts as anti-microbial, antiinflammatory, anti-proliferative and anti-fungal agent hence helps in early wound healing \& early healing prevents scar formation.

Palandu ghrita has shown Krumighna, Sukharopaniya, Sthirdhatukarta and Varnya properties in the management of Sadyovrana and prevents hypertrophic scar.

Palandu is madhur rasatmak which helps in sandhan karma of vrana. effective.

Method of application is easy, simple and cost

As per morphology, Palandu is made up of very thin layers just like human skin. So according to Samanya Vishesh sidhant we conclude that each layer of Palandu acts on each layer (7 layers) of human skin for wound healing. 


\section{References}

1. Bramhananda Tripathi, Charak Samhita -Purvardha Chaukhamba Surbharti Prakashan, Varanasi. Reprint-2001 Page no.328

2. Das S, A Concise Textbook of Surgery, S. Das Publication, Kolkata, $8^{\text {th }}$ Edition, 2014, Page no.1.

3. Anantaram Sharma, Sushrut Samhita, Part 1, Chaukhamba Surbharati Prakashan, Varanasi 2013,Page no.189.

4. Anantkumar Shekokar \& Dr. Kanchan Borkar, Textbook of Shalyatantra, Part 1, Shantanu Prakashan, Ahemadnagar, 2014, Page no. 466,467.

5. Nan A K, Undergraduate Surgery, Academic Publishers, $3^{\text {rd }}$ Edition, 1997, Page no. 47.

6. Das S, A Manual of Clinical Surgery, S. Das Publication, Kolkata, $11^{\text {th }}$ Edition, 2015, Page no.54.
7. Anantaram Sharma, Sushrut Samhita,Part 1, Chaukhamba Surbharati Prakashan, Varanasi 2013,Page no.417.

8. Allium Cepa: A traditional medicinal herb and its health benefits by J. Chem. Pharm. Res, 2010,2 (1):283-291

9. Das S, A Concise Text Book Of Surgery, S. Das Publication, Kolkata, ${ }^{\text {th }}$ Edition-2014, Page No-89.

10. Krushnachand Chunekar,Bhavprakash Nighantu, Chaukhambha Bharti Prakashan, Varanasi, $9^{\text {th }}$ Edition,Page no.-135 .

11. Bramhanand Tripathi, Sharangdhar Samhita, Chaukhamba Surbharti Prakashan, Varanasi, Reprint 2007, Page no.59. 